\title{
RULE-FOLLOWING AND RULE-BREAKING: KIERKEGAARD AND WITTGENSTEIN
}

\author{
DANIEL WATTS
}

\begin{abstract}
My aim in this paper is twofold: to establish that Kierkegaard's so-called 'theory of the leap' strongly anticipates a line of argument that is central to Wittgenstein's so-called 'rule-following considerations'; and to begin to show how Kierkegaard's work has fruifful contributions of its own to make to on-going discussions about rules and rule-following. The paper focuses throughout on the question of how, if at all, buman rule-following can be distinguished from behaviour that is merely mechanical or instinctual. I identify a central line of argument in Wittgenstein that problematizes this question by establishing the basis our ability to follow rules in our spontaneous responses. I argue that Kierkegaard not only strongly anticipates this line of argument but also offers a distinctive story about what, at bottom, makes the difference between buman rule-following and behaviour that is merely mechanical or instinctual. In a word, on Kierkegaard's story, what makes the difference is: anxiety.
\end{abstract}

Wittgenstein was not often given to effusive praise of other philosophers. But it is well known that he held Kierkegaard in singularly high regard, as 'by far the most profound thinker' of the nineteenth century.1 Studies on the relationship between the two thinkers naturally gravitate towards topics in the philosophy of religion, topics more to the fore in Kierkegaard than in Wittgenstein.2 My aim here, however, is to bring into view a wider field of philosophical common ground, with reference to the so-called rule-following considerations. I hope to show how Kierkegaard's work not only anticipates Wittgenstein's on this score but can help to advance on-going debates about rules and rule-following.

While these debates have branched off in many directions, I shall focus on the following core problem. On the one hand, we may want to distinguish the idea of an agent's following a rule from the idea of behaviour that merely conforms or adheres to a rule. We may want, for 
example, to be able to distinguish what is involved when a person understands the concept red, or the term 'red', from what is involved when a computer is set up to churn out tokens of this term just in case a red object passes by a sensor.3 By the same token, we may want to distinguish human rule-following from the mere regularity of instinctual behaviour that is exhibited, for instance, by hoverflies.4 On the other hand, however, there are good reasons to think the distinction between following and conforming to rules cannot be so clear-cut. For, there are good reasons to think that human rule-following must at some point be non-reflective, nondiscursive, non-ratiocinative: in a word, spontaneous. As I shall argue, these reasons are decisive for Wittgenstein's discussion of rule-following.

The problem is then whether we can specify a difference in kind between ruleconforming and rule-following, if not by reference to acts of reflection and explicit interpretation. Against this background, I shall argue (in §II) that Kierkegaard's work strongly anticipates Wittgenstein's argument that our ability to follow rules ultimately relies on our spontaneous responses. We shall see that essentially the same argument is what Kierkegaard will sometimes call, 'my theory of the leap'. However, I want further to show how his work can help us to advance a certain account of the difference in kind between rule-conforming and rulefollowing, given that this difference cannot essentially consist in the human capacity for acts of reflection. Specifically, I shall show (in \$III) how Kierkegaard's work supports the view that what makes the difference is, rather, the human capacity for anxiety. On this view, to follow a rule is not to break it, in the case that one is prone to anxiety about the possibility of breaking it.

\section{Rule-following, Rule-conforming and the Principle of Spontaneity}

A computer might be set up to produce tokens of the term 'red' just in case a red object passes a sensor. We naturally suppose that a human being who correctly applies the term 'red' understands the meaning of this term in a way this computer does not. But what makes the difference? One powerfully intuitive line of thought is as follows. Unlike the computer, the human rule-follower is able to reflect on the rules to which she adheres, interpreting them and basing her actions upon them. This, then, is what understanding amounts to in this context: having an interpreted rule in mind as one's guide and goal. Whereas the computer merely conforms to the rule, the human thinker follows the rule. In his Logical Investigations, Husserl gives lively expression to this line of thought, with reference to 'calculating machines': 
The machine [sc. the 'calculating machine'] is no thought-machine, it understands neither itself nor the meaning of its performances. But our own thought-machine might very well function similarly, except that the real course of one kind of thought would always have to be recognized as correct by the insight brought forth in another. This latter thinking could be the product of the same or other thought-machines, but ideal evaluation and causal explanation would none the less remain disparate. (Husserl 2001: 50)

Like calculating machines, human thought-machines function by means of rules. But, on Husserl's picture, there is this crucial difference: whereas the calculator is merely caused to behave in accordance with rules, thought-machines bring themselves into conformity with rules. They do so through special mental acts, of recognizing and evaluating, interpreting thoughts and detecting for themselves the rule-governed relations among them.

It follows from the picture of human thinkers as self-regulating thought-machines that human rule-following is essentially reflective. The relationship between the thinker and her acts of applying rules must, that is, be marked by a certain 'reflective distance': were this not so, there would be no room for the intermediary mental acts of interpretation and evaluation that are said to distinguish human rule-following from the merely mechanical. To put this implication contrapositively: when humans do adhere to rules unreflectively, they are merely conforming to rules, not really following them. There is a caveat here, however. For, it may be held that, compatibly with the idea of a thought-machine, a given slice of unreflective behaviour will count as genuine rule-following provided that, in the longer view, the behaviour involves the 'internalization' of an original process of reflection.5 This is how an advocate of the picture of human thinkers as self-regulating thought-machines is likely to try to accommodate the apparent fact that much of our rule-following is tacit and unreflective.

The line of thought just sketched approaches an 'intentionalist' account of rulefollowing. On any intentionalist account, to follow a rule is to apply the rule on the basis of an explicit representation of what it requires. Notably, intentionalist accounts are tenacious, still to be found in sophisticated discussions of rule-following in the wake of the classic problematizing interventions of Wittgenstein and Kripke. Thus, for instance, Paul Boghossian has it that, quite generally, what we properly call following a rule requires 'an intentional attempt to bring one's behavior in line with the dictates of [the] rule' (Boghossian 1989: 517).6 Likewise, David Bloor proposes a 'conscientiousness condition', according to which a rule is followed if and only if 'the actors bring about the conformity of their behaviour with the rule by intending to follow it' 
(Bloor 1997: 44). Bloor adds that, to count as genuinely following it, rule-followers 'must, as it were, have the rule before their mind as their guide and goal' (idem).7

I believe that Wittgenstein has shown that intentionalist accounts of rule-following cannot be right. Notably, the argument that shows this can be run independently of the issue that Kripke placed at the centre of the rule-following debates: viz. whether or not there are any 'facts of meaning' such as to fix the correct application of terms; that is, whether or not statements of meaning admit of a truth-conditional analysis. To anticipate: the argument of interest to us here turns instead on the claim that the intentionalist account implies, incoherently, that before a person can learn how to apply a rule he or she must already be in possession of this very ability. It is fundamentally for this reason that—as I think Wittgenstein has shown-the picture of human thinkers as self-regulating thought-machines cannot be right.

Wittgenstein's argument can be introduced by a passage from The Blue Book. 'Our problem', he writes, 'is analogous to the following:'

If I give someone the order, "fetch me a red flower from that meadow", how is he to know what sort of flower to bring, as I have only given him a word? Now the answer one might suggest first is that he went to look for a red flower carrying a red image in his mind, and comparing it with the flowers to see which of them had the colour of the image. Now there is such a way of searching and it is not at all essential that the image we use should be a mental one ... But this is not the only way of searching and it isn't the usual way. We go, look about us, walk up to a flower and pick it, without comparing it to anything. To see that the process of obeying the order can be of this kind, consider the order "imagine a red patch". You are not tempted in this case to think that before obeying you must have imagined a red patch to serve you as a pattern for the red patch which you were ordered to imagine. (Wittgenstein 1975a: 3)

Wittgenstein allows there is such a thing as reflecting on an order, figuring out what it means and then proceeding to execute it. By the same token, he allows there is such a thing as following a rule by bringing one's behaviour into conformity with an explicit interpretation of what the rule requires. He allows, then, that what the intentionalist says about human rule-following as such is apt to describe some ways we can follow rules. Wittgenstein's objection to intentionalist accounts of rule-following therefore in no wise relies on any general scepticism, of a behaviouristic stamp, about 'the inner'. His claim, however, is that the internal representation of a rule cannot be essential to following it. 
Wittgenstein gives two reasons. The first is that the function of any internal representation of a rule could be discharged just as well by an external representation: a colour chart, for instance. His second reason, however, applies to all representation, whether internal or external. Stated generally, the reason is that reflecting on a representation of a rule cannot be a prior condition of one's understanding how to apply it, since, for any $x$, to regard $\mathrm{X}$ as the representation of a certain rule is already to deploy a certain understanding of how the rule is to be applied. For this reason, Wittgenstein insists that, at some point, our application of rules must be immediate and direct: more like walking straight up to something (or someone) than following a map.8 At the ground level, there can be no intermediaries between thinkers and the application of rules: whether mental images, colour charts, Russellian Propositions, Fregean Thoughts or any other mediating item.9 That is to say, rule-following is ultimately grounded in the spontaneous - that is, non-reflective, non-discursive-responses of rule-followers.

This argument relies on the premise that to take something to represent a certain rule is already to deploy a certain understanding of how the rule is to be applied. Wittgenstein's reason is by now well-trodden ground: namely, that putative representations of rules are not selfinterpreting. On the contrary, they are multiply interpretable. In the classic illustration: any finite series of numbers instantiates indefinitely many rules for extending the series. In order for such a series to serve to represent one rule rather than another - the rule for addition, say, rather than Kripke's quaddition - it must therefore be taken up as such. Mere signs—squiggles on a page, for instance-are never representations of rules per se, for the question can always arise how the signs are to be taken up and projected, how they are to be used. In the terminology of the Tractatus, a representation is never a mere sign but a symbol, that is, a sign in use. It is for this reason that Wittgenstein maintains that to take something to represent a rule is already to deploy a certain understanding of how the rule is to be applied, that is, used. Given that it is of the nature of rules to apply to indefinitely many cases, any finite set of examples can be understood to represent a certain rule only on the basis of an established method of use.

A second premise of Wittgenstein's argument, however, is a general principle that has been identified by David Bell, under the title, 'The Principle of Spontaneity':

If the performance of an act of type $\Phi$ is learned or rule-governed, then it cannot be a general requirement of my performing an arbitrary act of type $\Phi$ that I have already performed an act of that type or, indeed, of any other type that in its turn requires the prior performance of an act of type $\Phi$. (Bell 1987: 225) 
Bell argues that, while crass infringements are rare, Frege's theory of judgement, for one, can be shown to violate this principle.10 For his part, Wittgenstein's recognition of the Principle of Spontaneity is in evidence already in the Tractatus, apropos the understanding of 'primitive signs':

The meanings of primitive signs can be explained by means of elucidations. Elucidations are propositions that contain the primitive signs. So they can only be understood if the meanings of those signs are already known. (Wittgenstein 1974a: 3.263)

Wittgenstein here applies the principle that understanding any given sign cannot require the prior understanding of some other sign, ad infinitum. Plausibly, moreover, it is because of his on-going concern with how to do justice to this principle that it is a returning question in Wittgenstein's later thought how the teaching and learning of language is even possible.11 In Philosophical Remarks, for instance, he puzzles over the difficulty that, since 'any kind of explanation of a language presupposes a language already', there is a sense in which language cannot be taught, 'i.e. I cannot use language to teach it in the way in which language could be used to teach someone to play the piano' (Wittgenstein 1975b: 54).12 Again, the difficulty is how to account for the possibility of one's coming to learn a language without presupposing the very thing to be explained.

Likewise, early on in the Investigations, the idea that 'the teaching of language is not explanation, but training' is set against the intellectualistic picture of language-learning sketched in the opening quotation from Augustine $(P I \$ \Phi 1,5)$. And when Wittgenstein begins his most sustained discussion of rule-following, his focus is expressly on the nature of the transition to linguistic understanding. Thus, we are invited to consider the case of teaching a pupil the series of natural numbers, where 'the possibility of getting him to understand will depend on his writing it down independently' (PI \$143, Wittgenstein's emphasis). The teacher gives examples, guides the pupil's hand, draws attention to patterns and the like: 'and now at some point he continues the series independently - or he does not' (PI $\ 145)$. The point of insisting that the pupil may (i.e. may, possibly) still respond aberrantly, all our explanations notwithstanding, is simply this: that his coming to understand cannot ultimately consist in his access to an explicit interpretation of the rule. On the contrary, 'the effect of any further explanation depends on his reaction' (PI \$145).13

Plausibly, then, Wittgenstein's discussion of rule-following turns on the Principle of Spontaneity. This observation supports the view that Kripke's reconstruction significantly diverges from this discussion. On Kripke's version, since rules are always underdetermined by any available evidence, there can be no fact of the matter about how a given term is to be 
applied, so that we face the threat of a general 'meaning-scepticism'.14 As McDowell and others have observed, this gets Wittgenstein's argument roughly backwards.15 The structure of his argument, rather, is that linguistic understanding cannot in general consist in acts of explicit interpretation, since if it did, one would already have to know how to apply a term before one could learn to do so- and that way lies the madness that rule-following is impossible. The moral is that '[o]nly the application of language can show how it is to be applied' (MSS VI: 70, cited in Baker \& Hacker 1980: 40) and that 'there is, for any rule, a way of taking it which is not an interpretation' (PI \$201). On this reading, it is only if we assume a faulty, intentionalist account of the nature of linguistic understanding that we will find ourselves saddled with a 'sceptical conclusion' about meaning.

Now, as we have noted, intentionalists are typically ready to concede that human rulefollowing is often tacit and unreflective. But Wittgenstein's objection still bites, even if we grant that the intentionalist can accommodate tacit rule-following via some account of the process in which prior acts of explicit interpretation get 'internalized'. For, the intentionalist still holds that, in the long view, behaviour that is to count as genuine rule-following must be based on prior reflection on representations of rules. And Wittgenstein's simple but powerful objection is that this cannot be right since, on the contrary, you cannot regard something as the representation of a rule without already knowing how it is to be applied.16 Reflection on representations always comes too late to be foundational for rule-following.

Let me summarize our discussion so far. Central to Wittgenstein's thought is an argument that tells against an intuitive way of trying to tell apart genuine rule-following from mere conformity to rules. This argument tells against any view, that is, in which the distinguishing factor is prior reflection on representations of rules. The argument relies on two key premises:

(1) To regard a given object, e. g. an image or a series of numerals, as the representation of a rule is already to deploy a certain understanding of how the rule is to be applied.

(2) It cannot be a general requirement of my performing an act of type $\Phi$ that I have already performed an act of type $\Phi$ ('The Principle of Spontaneity').

The upshot is that, if there is a difference in kind between mere rule-conforming and human rule-following, this cannot turn on the presence or absence of prior acts of reflection. The argument does not prove that there is no real difference between rule-conforming and rulefollowing. Philosophers who deny there is any such difference are of course free to use the 
argument as part of their case for this conclusion. Some, indeed, are prepared to grasp the nettle that human rule-following is reducible to mere regularities of behaviour-of the kind exhibited, for instance, by hoverflies.17 But this reduction is a further step. That it is not a step that Wittgenstein himself was prepared to take is suggested by such remarks as the following:

One follows the rule mechanically. Hence one compares it with a mechanism.

"Mechanical" — that means: without thinking. But entirely without thinking? Without reflecting. ([1956] VII-60, p. 422)

The suggestion here is that it is a mistake to conflate the idea of unreflective rule-following with the idea of behaviour that is mindless, automatic, merely mechanical or instinctual. Is there then some way of distinguishing genuine rule-following from mere regularity of behaviour sans appeal to prior acts of reflection? In the final section of this paper ( $(\mathrm{III})$, I want to show how Kierkegaard's work can help us to make headway with just this question. Firstly, however, I hope to bring out the striking way in which Kierkegaard anticipates the insights that we have seen to be decisive for Wittgenstein's discussion of rule-following.

\section{Logic, Language and Kierkegaard's 'Theory of the Leap'}

Kripke imagines a sceptic who insists that 'when I answered ' 125 ' to the problem ' $68+$ 57', my answer was an unjustified leap in the dark' (Kripke 1982: 10). It turns out that Kripke is not the only writer on the topic of rule-following to have been drawn to this image, the image of a leap.18 Witness the following from Norton Batkin:

It is in the context of a particular training or of particular practices already mastered that a moment of pointing teaches us or defines for us a use of a word. Learning the use of a word is ... a matter of leaping from practice to practice. From this training I leap to that practice, from that practice I leap to another. From repeating the words "block", "slab", "beam" after the teacher, I leap to repeating the words as he points to differently shaped stones and says "block", "slab", "beam". And then I leap to saying the words out loud as he points, silently, to the stones.' (Batkin 1993: 255) 
Batkin evidently thinks the kind of agency involved in language-learning is somehow best captured by the verb, to leap. The same trope shows up also in the introductory essay to the collection to which Batkin's paper contributes, compiled in honour of Stanley Cavell:

[T] he use of language for the description of our own state as well as those of others requires a leap of faith in what Cavell calls "our mutual attunement." This leap seems less dramatic than Kierkegaard's leap of faith in religious life but far more pervasive; it characterises the whole of life with others and ourselves. (Cohen, Guyer \& Putnam 1993: 6)

I want now to show how, far from being restricted to religious life, Kierkegaard's own use of the symbol of 'the leap' bears in a quite direct way on discussions about rule-following. Specifically, we shall see how Kierkegaard applies the Principle of Spontaneity to human thought and language quite generally.19 (I shall leave aside the possibility that, for Kierkegaard, our mundane practices of rule-following involve leaps no less 'dramatic' than the sort he associates with religious faith.)

That Kierkegaard's 'leap' is not just about religious life is easily shown.20 In one journal, for instance, he is to be found asking whether 'all of life' does not consist in the fact that no transition 'from a quantitative to a qualitative determination [can] occur without a leap' (JP 1: 261). Other passages associate the idea of a leap, qua transition 'from a quantitative to a qualitative determination', with the sorites paradox and with the idea that the emergence of new qualities cannot in general be explained by merely incremental ('quantitative') processes.21 Quite generally, moreover, Kierkegaard's work exhibits a special interest in the sorts of transition that are involved in non-genetic learning, whereby individuals acquire the sorts of qualities that are sometimes associated with our 'second nature': language, a moral culture, sin-consciousness and so forth. But why associate such transitions with a leap?

A journal from 1844 refers to something called 'my theory of the leap' (JP 3: 2352). This appellation is perhaps playful. But the first point to notice about the thoughts to which Kierkegaard refers in this way is their source in considerations not about religious faith but about logic. His first major remarks on 'the leap' are these:

Basic principles can be demonstrated only indirectly (negatively). This idea is frequently found in Trendlenburg's [sic] Logische Untersuchungen. It is significant to me for the leap .... By analogy and induction the conclusion can be reached only by a LEAP. (JP 3: 16) 
These lines testify to Kierkegaard's stake in the hotly contested debates of his day around Trendelenburg's so-called 'Logical Question'. At issue in these debates was the status of the basic principles of traditional logic: i. e. the principles of non-contradiction, identity and excluded middle, along with, in Aristotle's terms, 'the first and immediate' premises of any body of scientific knowledge. Fresh controversy about these topics had been ignited by the decidedly non-traditional approach to logic embodied in Hegel's claim to have constructed a wholly self-standing logical system, perfectly free from underived premises or principles. 22 Trendelenburg's Logical Question was then just this: 'Is Hegel's dialectical method of pure reasoning a scientific procedure?' 23

Trendelenburg had answered his question firmly in the negative. And Kierkegaard picks up on two Aristotelian ideas behind this verdict. First, he picks up on the idea that, while they may admit of some indirect or negative form of demonstration, some things cannot be directly or positively demonstrated; that is, they cannot be derived from anything more basic or secure. Aristotle famously treats the principle of contradiction as a paradigm case of something 'indemonstrable' in this sense, since 'in general it is impossible for there to be a demonstration of everything (for in that case demonstration would proceed to infinity and so there would be no demonstration)' (Metaphysics 1006ª-11). Second, Kierkegaard picks up on the idea that, by the same token, demonstrative reasoning ultimately depends on certain kinds of non-deductive, non-inferential judgement. Aristotle's recognition of this point shapes his distinctive conception of epagoge - usually but, as is often noted, misleadingly translated 'induction' - as the non-discursive means by which mind is able to directly perceive the universal in the particular and thereby establish the first premises of a demonstrative science (Posterior Analytics 100a-b; cf. Prior Analytics 67a22ff).24

What then have these themes in Aristotelian logic to do with the idea of a 'leap'? We can see why the image might suggest itself here, if we only bear in mind that leaping can be useful when you need to get from A to B without touching the intervening ground. Against the background of the idea of a demonstration that proceeds 'to infinity', that is, the idea of a leap is apt to symbolize the thought that, since no finite thinker could traverse a series of judgements based on prior judgements ad infinitum, demonstrative reasoning must ultimately rely on acts of judging that are immediate and direct. This, I take it, is just what Kierkegaard means by a 'leap' in this context: that is, a primitive act of judging, in the sense of an act of judging that is unmediated by any prior judgement. 
The sort of leap at issue here is nicely illustrated, via negationis, by the sort of performance that the Tortoise declines to venture in Lewis Carroll's cautionary tale about deductive reasoning (Carroll 1895). Having completed Zeno's race-course of infinitely diminishing distances, Carroll now has the exasperated Achilles goaded to run through a proof that does indeed 'proceed to infinity', by having the Tortoise recursively treat the relation of logical consequence itself as a suppressed premise of the proof. Unlike Zeno's race-course, as Carroll wittily observes, Achilles' problem here is not soliviter ambulando, not solvable by walking (Carroll 1895: 691).

The insight that even highly systematic forms of reasoning ultimately rely on primitive acts of judging ramifies widely in Kierkegaard's work. One example is his critique of rational theology. Johannes Climacus, Kierkegaard's fictional philosopher, expresses his 'final reservation' about rational theology as the observation that, however impressive the battery of theistic arguments at one's disposal, the judgement that God exists could never be literally forced on one by logic, but could always only result from a 'leap' on the part of a thinker ( $K W$ VII: 43). This leap, which Climacus also characterises as a 'letting go', is always 'meine Zuthat', the thinker's own contribution (KWVII: 43). (Compare Carroll's Tortoise's flat-footed response to Achilles' appeal to the idea that, were you to endorse the premises of a valid argument, 'Logic would take you by the throat, and force you' to accept its conclusion (Carroll 1895: 693, Carroll's emphasis).25) Climacus frames this as point about the limits of rational theology, but this aspect of his critique is really quite general, regarding demonstrative reasoning as such. His point is that, in the last analysis, it is not arguments that make judgements, but thinkers.

The insight that even highly systematic forms of reasoning rely on primitive acts of judging also animates the Trendelenburg-inspired attack on Hegel developed in Concluding Unscientific Postscript. In Climacus' view, Hegel's grand vision of a system of 'pure thought'-as a sort of self-generating, perfectly reflexive thought-machine-could only be a 'pure chimera' inasmuch as, according to its conception, this machine is disconnected from the concrete performances of existing human thinkers.26 Accordingly, 'the system' is said to betray a comic forgetfulness that even the most abstract thought relies in the end on 'the act of the abstracter' and that 'the abstracter is, after all, an existing person' (KW XII: 315). Likewise, in his attack on Hegel's claim to have made an 'absolute beginning' in logic, Climacus insists that no logical system could be set in motion without the aid of 'something altogether different from the logical' (KWXII: 113)—namely, the agency of the thinker. Accordingly, the question 
Climacus wants to press in this connection is this: 'What if, rather than speaking or dreaming of an absolute beginning, we speak of a leap?' (KW XII: 115)

I submit, then, that what Kierkegaard calls his 'theory of the leap' turns on the principle we identified (in $\ I$ above) as pivotal to Wittgenstein's discussion of rule-following, viz. the Principle of Spontaneity. If this is right, it is salutary not to mistake Kierkegaard's 'leap' for an appeal to the idea that, within any given set of beliefs, some legitimately have a fixed or foundational status. When Climacus deploys the symbol of a leap in his critique of rational theology, for example, this is not part of an apologetic aim to show, in the style of 'reformed epistemology', that we are warranted to treat belief in God as foundational or 'properly basic' (see Plantinga 1982). What Kierkegaard treats as primitive in this connection is not types of beliefs or propositional contents but, rather, token acts of judging.

We can further see how the Principle of Spontaneity is behind Kierkegaard's interest in 'the leap' if we briefly consider how this symbol enters into his treatment of a quite different topic: the genesis of $\sin$. Vigilius Haufniensis, the fictional author of The Concept of Anxiety, sums up one of his central claims by the slogan, 'sin comes into the world ... by a leap' (KW VIII: 36). Again, the image of a leap gains its traction here against the background of the threat of a vicious regress: in this case, a regress of acts of sin based on prior acts of sin. Thus, Haufniensis satirizes the tendency, in attempts to explain the transition from innocence to guilt, to end up describing the initial state in a way that already smuggles in the explanandum: 'the projected innocence is changed little by little into sinfulness, and so there it is' (idem). Haufniensis has in mind such traditional explanations of the Fall as 'concupiscence', where the worry is that to ascribe inordinate desire to prelapsarian humans, and then to try to explain the genesis of sin on this basis, is to beg the question. The genesis of sin, Haufniensis insists, cannot be incremental.

Now, the slogan, 'sin comes into the world by a leap', itself hardly looks like much of an explanation. Haufniensis fully recognizes this. But he defends his slogan on the grounds that it at least honestly registers the limits of explanation in the face of a fundamental paradox regarding the genesis of sin. The paradox is the appearance that the act by means of which a person first acquires the capacity to sin must itself already be the exercise of this very capacity. As Haufniensis puts it rather darkly, 'sin comes into the world as the sudden, i.e. by a leap; but this leap also posits the quality, and since the quality is posited, the leap in that very moment is turned into the quality and is presupposed by the quality and the quality by the leap' (idem). Drawing attention to this paradox, in which a new capacity seems to be acquired only through its very exercise, is evidently part of the point of the image of a leap in the first 
place. What is helpful about the image in this regard is that leaping is the sort of activity in which, as Climacus puts it elsewhere, a person is 'closest to being in two places at the same time' (KWXII: 199).

I shall shortly suggest (in \III below) that Haufniensis' discussion of the genesis of sin has a more direct bearing on the problem of rule-following. But the point for now is just to highlight the strong isomorphism between this discussion and both Wittgenstein's insistence on the Principle of Spontaneity in his thinking about rule-following and Kierkegaard's application on this same principle to logic and systematic thought. Thus, for example, Haufniensis' paradox, in which a new capacity seems to be acquired through its very exercise, is strongly echoed in the following from Wittgenstein:

However many intermediate steps I insert between the thought and its application, each intermediate step always follows the previous one without any intermediate link, and so too the application follows the last intermediate step. It is the same as when we want to insert intermediate links between decision and action ... We can't cross the bridge to the execution until we are there. (Wittgenstein 1974b \$110)27

Given that there are no intermediaries to tell you how to apply a rule, the difficulty is that it then looks as though the act by means of which you first acquire the ability to apply the rule must already involve this very ability. In Wittgenstein's image, it is as though you were to need to have already crossed a bridge before you could cross it. This paradox is exactly isomorphic with the one Haufniensis associates with the genesis of sin. In both cases, the root problem is how to do justice to the Principle of Spontaneity. It even turns out that Wittgenstein himself was not immune from the pull of the image of a leap in this connection. Of the transition from one's grasp of the meaning of a given term to one's actually applying it in a given situation, he says in one place that 'at this transition all rules leave me in the lurch ... in the end I must make a leap' (MS 129, cited in Baker \& Hacker 1985:148).

Wittgenstein's focus is of course on linguistic understanding. So far, we have seen how Kierkegaard deploys the symbol of a leap to specify primitive acts of judging and primitive acts of sin. Is there then any evidence that he saw his 'theory of the leap' as bearing specifically on linguistic understanding? An affirmative answer is indicated by such passages as the following: 
If it were true that philosophers are without presuppositions, an account would still be due of language and its whole importance for speculation. For here speculation has indeed a medium which it has not provided for itself ... Language [is] partly an original given and partly something that freely develops ... though we do at times find the ill-conceived tendency not to want to accept language as a freely appropriated given but rather to give it to oneself ... where it usually ends in silence or in the personal isolation of a jabbering argot. Perhaps the story of the Babylonian confusion of tongues may be explained as an attempt to construct an arbitrarily formed common language, which attempt, just because it lacked fully integrative commonality, had to break up into the most scattered differences, for here it is a question of totum est parte prius, which was not understood. (Kierkegaard 1996: 130)

This passage is remarkable not least for the way it anticipates the principle of a more recent philosophy of language that the whole is prior to its parts. As H. J. Cloeren has observed, it also anticipates 'the linguistic turn' (Cloeren 1985: 125). But the core idea is that language is both 'freely developed' by the members of a linguistic community and given to them in the form of the 'fully integrative commonality' of their language as a whole. 28 In the punning formula Kierkegaard liked to apply to the whole of life, language is essentially both gift (Gave) and task (Opgave).29 And he is quick to draw the moral that were someone - a Hegelian philosopher, say - to try to construct a language of pure thought, severed from all connections with our everyday life with language, this could only really end in silence or a ‘jabbering argot'.30

I hope to have shown that Kierkegaard anticipates Wittgenstein's argument that our ability to follow rules ultimately relies on our spontaneous responses. We saw (in $₫ I$ above) how this argument tells against an intuitive way of trying to tell apart genuine rule-following from mere rule-conforming. As we also noted, however, Wittgenstein evidently does not want to give up this distinction itself. I think we can make the same point about Kierkegaard. For, it is an entirely Kierkegaardian thought that the very same linguistic behaviours that sometimes express genuine understanding at other times do not. Haufniensis, for instance, introduces the memorable image of a 'talking machine':

Spiritlessness can say exactly the same thing that the richest spirit has said, but it does not say it by virtue of spirit. Man qualified as spiritless has become a talking machine, and 
there is nothing to prevent him from repeating by rote a philosophical rigmarole, a confession of faith, or a political recitative. (KWVIII: 95)

Notwithstanding his opposition to intellectualistic accounts of what makes the difference between speech-acts that genuinely express human 'spirit' and the outputs of a 'talking-machine', there is every indication that Kierkegaard nonetheless wants to hold on to the distinction itself. So again we arrive at the question: is there then some way to distinguish human rule-following from mere regularity of behaviour without appeal to prior acts of reflection?

\section{\$3 Adam's Angst: Rule-breaking in Eden}

The problem that has emerged from our discussion so far is whether there is a way to respect the Principle of Spontaneity without reducing human rule-following to behaviour that is merely mechanical or instinctual. Can we throw out the intentionalist bathwater while saving the idea of a distinctively human way of following rules? One way to approach this problem is to look for an alternative distinguishing factor, one that does not build reflective self-regulation into the very idea of rule-following. Drawing further on Kierkegaard's Concept of Anxiety, my aim in the remainder of this paper is to begin to develop a proposal of this sort. On this proposal, what distinguishes human rule-following from mere regularity of behaviour is not fundamentally our capacity to reflect on represented rules. Rather, what makes the difference is our capacity for a certain kind of affective relationship towards the possibility of rule-breaking: specifically, a form of what Kierkegaard calls anxiety. On the account I want to canvass, to conform to a rule is simply not to break it; by contrast, to follow a rule is also to be disposed to feel anxious about breaking it, where such anxiety typically remains latent but can sometimes come to the surface.

A first step towards this proposal is to afford the concept of rule-breaking a certain priority over the concept of rule-following. That is, we can treat rule-following as a so-called excluder concept, like the concept of being voluntary, for example, under any analysis in which being voluntary is not being coerced.31 On this negativistic approach, to follow a rule is not to break it. This approach allows us to conceptually dissociate rule-following from the idea of mental operations on represented rules: acts of reflection, interpretation and the like. To be sure, this negativism does not by itself establish a difference between rule-following and ruleconforming. After all, we may just as well treat rule-conforming on the same model: to conform to a rule is not to break it. Treating rule-following and rule-conforming as excluder concepts, however, allows us to look for a distinguishing factor of the following sort: one that specifies a 
distinctive relationship between rule-followers and the possibility of rule-breaking. Kierkegaard's conception of anxiety, I want to suggest, can help us to specify just such a relationship.

How, then, does Kierkegaard conceive of anxiety, as a feature of human psychology and in relation to the possibility of rule-breaking? Chapter One of Anxiety offers a novel reading of Genesis 1-3 which turns on the question of how we are to understand Adam's response to the prohibition not to eat from the Tree of Knowledge of Good and Evil. Central to Haufniensis' interpretation is the connection he makes between Adam's innocence and his ignorance. However exactly we are to parse 'the knowledge of good and evil', we know that, in his innocence, Adam does not yet possess this knowledge. On Haufniensis' interpretation, this means he is not yet able to bring possible courses of action under the concepts of good and evil. He is not, for example, in a position to represent eating from the forbidden tree as evil. But the difficulty runs deeper still. For, the terms 'good' and 'evil' are of course included in the prohibition itself, in the very title of the off-limits tree. So the question arises how Adam can understand this prohibition at all.32 Haufniensis identifies this issue sharply:

When it is stated in Genesis that God said to Adam, "Only from the tree of the knowledge of good and evil you must not eat," it follows as a matter of course that Adam really has not understood this word, for how could he understand the difference between good and evil when this distinction would follow as a consequence of the enjoyment of the fruit? ... After the word of prohibition follows the word of judgement: "You shall surely die." Naturally, Adam does not know what it means to die. (KWVIII: 44-45)

One difficulty this raises is how, in view of Adam's ignorance, it can be just for God to hold him to account. This theological problem falls well outside my remit here. In order to bring into focus the non-theological dimensions of his discussion, however, we can follow one of Haufniensis' more unorthodox suggestions. He suggests that we need not think of the prohibition as 'coming from without', from God, but rather as having its source in the language that Adam already speaks:

Innocence can indeed speak, inasmuch as in language it possesses the expression for everything spiritual. Accordingly, one need merely assume that Adam talked to himself. The imperfection in the story, namely, that another spoke to Adam about what he did not understand is thus eliminated. From the fact that Adam was able to talk, it does not follow in a deeper sense that he was able to understand what was said. This applies above all to the 
difference between good and evil ... Innocence can indeed express this difference, but the difference is not for innocence. (KWVIII: 45-6, my emphasis)

From this perspective, the question we are really asking, when we ask whether he understands God's command, is whether Adam understands the language he already speaks.33 Haufniensis' answer is two-sided. In one way, prelapsarian Adam does not understand the language he speaks. For, we are to suppose that this language expresses (for example) a contrast between good and evil and that he is not yet in a position to apply these concepts: the difference is not thematically there 'for' him. But, in another way, Haufniensis evidently holds that Adam's capacity to feel anxious about a particular (moral) prohibition already implies a certain familiarity with language.

I shall return below to the question of what this background linguistic familiarity might involve. But the point of his insistence that Adam must in some way already speak a language becomes clearer if we return to Haufniensis' exposition of Genesis. For, his claim is not that 'the word of prohibition' is utterly unintelligible to Adam. Rather, he holds that this word is enigmatic, riddle-like. It is this feature that is said to elicit Adam's Angst: ‘[b]ecause Adam has not understood what was spoken, there is nothing but the ambiguity of anxiety' (KWVIII: 45). In the face of the enigmatic prohibition, that is, Adam becomes anxiously aware that there is something he could do, though he knows not exactly what; something that, in some unforeseeable way, would tear through the very boundaries of his world; a naked possibility that, as such, he finds both attractive and repellent, fascinating and terrifying. Anxiety thus attaches in the first instance to Adam's inchoate awareness of himself as a potential rule-breaker.

The idea here is plainly not that his anxiety somehow guarantees Adam's obedience. On the contrary, the main burden of Chapter One of Anxiety is to show how his anxious fascination with the possibility of transgression can help to explain - though not to necessitate - the first sin. It is a consequence of this account that, so long as Adam continues to adhere to the prohibition, his doing so is qualified both by his inability to determinately grasp its content and by his anxious orientation towards the possibility of doing otherwise. But we are to suppose that this situation is precarious from the outset, as though Adam were trying to keep to a path he cannot clearly make out beside an abyss into which he is continually tempted to peer. 34 On Haufniensis' account, this reflects the fundamentally ambivalent character of anxiety: while Adam's natural antipathy towards the prohibited possibility makes him want to steer clear, the fascination it also holds for him prevents him from falling back into mindless conformity.

Now, by way of this reading of the Genesis narrative, Haufniensis evidently means to offer an account of anxiety as a primitive feature of human psychology quite generally. Thus, he 
claims that the anxiety typified by Adam is present in all human culture, or at least in all cultures where the childlike is preserved' (KIV VII: 42).35 We should therefore ask what this story about anxiety comes to, if we abstract from the details about Adam and Eden. The core idea, I submit, can be captured the following three conditions: interest; indeterminacy; and agent's-awareness.

Firstly, anxiety is possible for us only because of the interest we take in possibilities as such. In Kierkegaard's lexicon, 'interest' is a mark of the human quite generally. Exploiting its etymology - from inter and esse, between and being - he deploys this term to describe humans, as beings to whom it belongs to take an interest in themselves and their environment, as existing 'between' actualities and possibilities.36 In this view, it is constitutively human to try to actualize possibilities and, correlatively, to regard given actualities as possibly other than they are. Thus, we are to suppose that part of what distinguishes Adam from 'the beast', even in his innocence and ignorance, is the interest he takes in possibilities as such, for himself and his environment. Were this not so, he could not respond to the prohibited possibility in the way envisaged. But quite generally, in Haufniensis' typological reading of the Genesis narrative, Adam's Angst is part of being human only because we are the kind of beings who take an interest in possibilities as such. In Merleau-Ponty's phrase, it is ours to 'reckon with the possible'.37

Secondly, this form of anxiety arises for us only because some of the possibilities in which we take an interest are ones we experience as highly indeterminate. Famously, Kierkegaard contrasts anxiety in this respect with states such as fear or worry. Unlike such states, whose intentional objects are typically well-defined, the object of anxiety is said to be, phenomenologically, 'nothing'. In the first instance, this means that the object of anxiety is a possibility that, while it is disclosed as such, eludes one's grasp: it is experienced as nothing determinate. This situation is typified by Adam: the possibility of transgression disclosed to him through the prohibition is one whose content and consequences he is poorly placed to render determinate. But quite generally, in the view Haufniensis develops in this way, anxiety is a part of being human only because some of the possibilities in which we take an interest are such that we are poorly placed to get them clearly into view.

Thirdly, among the possibilities in which we have an interest but experience as indeterminate, some of these are ones we regard as alternative possibilities for action. Were our interest only in possibilities experienced as wholly beyond our control, Kierkegaard evidently takes it that anxiety, in the form he finds typified by Adam, would not arise for us. And he thinks that awareness of possibilities as possibilities for action requires, in turn, a kind of self-awareness: namely, the awareness of oneself as an agent. Crucially, such agent's-awareness need not be reflective and thematic. 38 Thus, Haufniensis ascribes to Adam a pre-reflective form of reflexive 
awareness, even in his innocence and ignorance. This is Adam's intermittent awareness of himself as both a 'friendly' and 'hostile' power-that is, as such that it is within his power either to help or to harm himself (KWVIII: 41-42). We are to suppose that this primitive selfawareness already sets Adam's comportment apart from the merely instinctual behaviour of 'the beast'. And we are to suppose that this self-awareness is what becomes engaged in a new way by the enigmatic possibility disclosed by the prohibition. As Haufniensis puts it, in the face of the prohibition, 'the nothing of anxiety has now entered into Adam ... [as] the anxious possibility of being able (KWVIII: 44). But again, in this respect also, Adam is supposed to typify a primitive human phenomenon: viz. our awareness of possibilities as possibilities for action and our correlative reflexive awareness as agents.

On the overall account, then, anxiety can take the form of an affective relationship towards possibilities that are experienced both as indeterminate and as such as to engage one's agency. Given our constitutive interest in possibilities as such, and in possibilities for action, the disposition to such anxiety is always latent in human psychology. But it varies in degree of manifestation: the more fully the conditions of interest, indeterminacy and agent's-awareness are met, the more manifest the anxiety. Accordingly, in Haufniensis' interpretation of Genesis, it is the prohibition that brings to the surface the anxiety that was always latent in Adam's psychology.

Now, my suggestion is that this general account can help us to specify a distinctive relationship between human rule-followers and the possibility of rule-breaking. The relationship is this: possibilities of rule-breaking, experienced as indeterminate possibilities in which we nonetheless take an interest as agents, are among the objects of anxiety. Because of this, our relationship to rules is not in general merely one of adherence or conformity: it is not merely that our behaviour admits of being described by rules. But neither do we typically have in mind determinately represented rules, as our guide and goal. Rather, for some of the rules to which our behaviour conforms, we are disposed to feel anxious about the possibility of breaking them. Crucially, on the proposal we are considering, this is already enough to distinguish human rulefollowing from the merely mechanical or instinctual. On this account, then, these two conditions are jointly sufficient for a way for person to follow a rule: that her behaviour conforms to the rule and that she is disposed to anxiety about breaking it.

Consider an example that quite closely fits Kierkegaard's model. A parent instructs a child never to lie. The child lacks a firm grip on what lying is. She is unsure, for example, how lies differ from inadvertent falsehoods.39 But she understands enough to become anxious about transgressing the prohibition. (It is not difficult to imagine that the prohibition elicits in the child 
an anxious fascination with the possibility of lying.) On the proposal we are considering, this child is now already in a way of rule-following: for so long as her behaviour conforms to the rule, this merely behavioural fact is no longer all there is to her compliance. She may, for example, start to second-guess herself ('Was that a lie?, 'Am I lying now?'). And this is so, despite the fact that, ex bypothesi, the child is not yet in a position to self-regulate by determinately representing the rule to herself and then trying to bring her behaviour into line.

None of this is to deny that human beings sometimes follow rules in higher-order, more reflective ways. As we observed above, Wittgenstein, for his part, gives us no reason to deny that human rule-following sometimes fits the intentionalist model, in which rules are applied by way of reflection on an explicit interpretation of what they require. On a natural development of Haufniensis' story about the awakening of human 'spirit', moreover, acts of rule-breaking play an important role in the transition from pre-reflective anxiety about rule-breaking to the explicit interpretation of the rules that have been broken. By the same token, this story also allows that much human rule-following may involve the subsequent internalisation of explicitly interpreted rules so that, if anxiety about breaking the rules remains, such anxiety typically remains latent. What the story does not allow, contra intentionalist accounts, is that applying a rule on the basis of a prior interpretation of what it requires is essential to genuine rule-following, as the factor that sets such agency apart from mere regularity of behaviour.

This account no doubt raises many questions and I shall not attempt a full defence here. Finally, however, let me consider two especially pressing objections.

A first objection is that, whatever we might want to say about Adam in Eden, it is implausible that anxiety is involved in most mundane cases of rule-following. It is surely implausible that the person who knows how to use the term 'red', for example, must be continually wracked with anxiety about getting it wrong. The following points may help to ease this worry. Firstly, on the account we have advanced, the disposition to anxiety typically remains latent. The account can therefore allow that conscious episodes of anxiety are not in the normal smooth running of our rule-following. On the other hand, it is not implausible that mundane cases of human rule-following do, to some degree, satisfy our three conditions: interest, indeterminacy and agent's-awareness. Consider, for instance, the complex web of norms surrounding greetings in different social contexts - handshakes, kissing, verbal greetings and the like - and the underlying unease one may feel about somehow getting it wrong. Plausibly, moreover, such awareness of the possibility of rule-breaking can sometimes become thematic. Thus, for example, episodes of anxiety about rule-breaking can be triggered by so-called 'breakdown' situations, in which the usual flow of life is disrupted. Upon arrival in a new country, for 
instance, in which one does not know one's way about, one's latent anxiety about social norms may suddenly be brought to the surface. And certain conditions may elicit anxiety even with respect to one's ability to 'go on' with a familiar term such as 'red': conditions such as tiredness, inebriation, unusual lighting or, again, exposure to a different culture.40

A second objection, however, is this. It might be insisted that a person could feel anxious about breaking a rule, or be disposed to such feelings, only if he or she has already grasped the very content of the rule. But if anxiety about rule-breaking presupposes the reflective grasp of rules then such anxiety surely cannot be basic in our account of what it is to follow a rule. On this line of objection, the proposed account could therefore only disguise, but not resolve, the problem of circularity that we have pressed above against intentionalist accounts.

In considering this objection, we should first acknowledge certain limits to the remit of our proposed account. What it purports to explain is a difference between human rule-following and mere rule-conforming. And it purports to explain this without recourse to the idea of acts of reflection on represented rules. But the account does not purport to provide a genetic story about how rule-following 'gets going' in human development, still less to explain 'the leap from protoplasm to personhood' (in Phillip Pettit's phrase). As we have emphasized above, with reference to his own use of the symbol of the leap, Kierkegaard will insist on there being inprinciple explanatory limits to any such developmental story.

We should also keep in mind in this connection that it is part of the proposed approach to treat rule-breaking as conceptually prior to rule-following. Adopting this approach has allowed us to formulate the claim that there need be no more to being a rule-follower than one's standing in a certain relationship to the possibility of rule-breaking. If it is not to beg the question, the envisaged objection therefore needs to be raised in a way that does not simply assume that rulefollowing is conceptually prior to rule-breaking.

Nonetheless, this second line of objection raises a serious concern. For, our proposal does purport to save the conforming/following distinction without appeal to acts of reflection on represented rules. It would therefore be fatal to the account if anxiety about rule-breaking turns out to presuppose reflection on represented rules. Plainly, much here turns on the question of whether anxiety presupposes reflection. And it should be clear that, in the view we have extrapolated from Anxiety, anxiety about rule-breaking need not presuppose a reflective, determinate grasp of the rule in question. It will not do so just in case the possibility of rulebreaking is one that satisfies the conditions of interest, indeterminacy and agent's-awareness.

We can register in this connection a telling contrast with Kant's Conjectural Beginnings of Human History. In his reading of Genesis, Kant also makes reference to anxiety. But, in his 
version of the story, anxiety is late on the scene, posterior to the genesis of fully reflective selfconsciousness.41 For Haufniensis, by contrast, the disposition to anxiety is latent from the beginning and is already brought to the surface by the enigmatic prohibition itself. Pace Kant, Adam is not originally hard-wired to act on instinct or incentive. Rather, we are to think of him from the outset as already given to a primitive, pre-reflective form of normative orientation, one that is bound up with his susceptibility to anxiety about the possibility of transgression, despite his being poorly placed to know what this possibility comes to or what might come of it.42

Still, even if it is granted that one could feel anxious about breaking a particular rule without having a determinate grasp of its content, it may look doubtful that such anxiety could be specified without reference to the reflective grasp of rules. For, the worry may remain that such anxiety presupposes, if not the grasp of the content of a particular rule, at least a general understanding of what rules are and of what counts as complying with them.43

In the context of Haufniensis' story about Adam, this way of pressing the objection returns us to the question of how we are to understand the sense in which he thinks Adam does understand the language he speaks. What linguistic facility must we think of Adam as having already acquired if we are to make sense of Haufniensis' description of his anxiety in the face of the prohibition? Haufniensis admittedly says little to address this question. But we may recall in this connection Wittgenstein's insistence that the teaching and learning of language cannot in general consist in the giving and receiving of explanations, but must at bottom involve practical attunement, through training, habituation and play.44 To the extent that this view is plausible in general, it is plausible that learning to respond to imperatives as such need not involve learning any explicit rules. No doubt it is a further, empirical, question how exactly children learn to discriminate some linguistic performances as imperatives, others as interrogatives, declaratives, subjunctives and so forth. 45 But the important conceptual point is that such learning need not involve the explicit grasp of rules. As Wittgenstein puts this general point, drawing again on his guiding analogy between learning a language and learning how to play a game, language 'can be learned purely practically, without learning any explicit rules’ (Wittgenstein 1975c \$95).

Again, however, one might further press the question whether anxiety about rulebreaking can really exist without a prior grasp of rules, given that it involves at least an implicit or practical understanding of what rules are and how to apply them. After all, it is natural to suppose that what it means to respond to an imperative, as such, just is to take it to prescribe certain courses of action and to proscribe others. Must Adam therefore know what rules are before he can respond to the 'word of prohibition' in the way Haufniensis describes? 
We have seen that, on Haufniensis' own view, if we are to think of him as responsive to the prohibition as such, we must think of Adam as already on the way to linguistic understanding. But from this it does not immediately follow that Adam must know, even implicitly or 'purely practically', what rules are and how to apply them, prior to and independently of his anxiety about rule-breaking. On the contrary, I think we can best make sense of Haufniensis' account if we suppose that Adam's emerging competence with language, together with his native susceptibility to anxiety, prepares him to spontaneously respond to the word of prohibition by feeling anxious about the possibility of doing whatever it is that this word prohibits. It will be plausible to say that, so described, Adam's response involves a newfound practical understanding of what a rule is. But his response presupposes neither a prior grasp of the content of the particular prohibition nor, more generally, a prior grasp of what it means to follow a rule. 46

In sum, then, I think we can with some plausibility extrapolate from Anxiety the idea of a primitive form of rule-following that is neither reflective and thematic nor merely automatic and mindless.47 Certainly, it would be unconvincing to claim that our capacity for anxiety is sufficient to explain the genesis of human rule-following in general. For his part, Kierkegaard makes no pretence of having explained how language emerges in the first place. And more work is needed to establish that such anxiety really is a distinguishing mark of human rule-following. However, in the light of the difficulties that we have seen to be central both to Wittgenstein's rulefollowing considerations and to Kierkegaard's 'theory of the leap', I submit that our capacity for anxiety about rule-breaking is at least a factor of the right sort to help explain the intuitive idea that human rule-following involves more than the merely mechanical or instinctual.

When Russell once asked Wittgenstein whether he was thinking about logic or his sins, the latter is said to have replied, 'both'.48 In this paper, I hope to have shown how Kierkegaard's thoughts, both about logic and about sin, strongly anticipate Wittgenstein's discussion of rulefollowing. I also hope to have made it plausible in this connection that Kierkegaard's work offers fruitful contributions of its own, not least to on-going debates about whether and how human rule-following can be distinguished from behaviour that is merely mechanical or instinctual.49

\section{dpwatts@essex.ac.uk}

School of Philosophy and Art History

The University of Essex

Wivenhoe Park

Colchester CO4 3SQ 


\section{References}

Baker, G. P \& Hacker, P. M. S (1980), Wittgenstein: Meaning and Understanding. Oxford: Blackwell. (1985) Rules, Grammar and Necessity. Oxford, Blackwell.

Barnes, J. (1984), The Complete Works of Aristotle. Princeton: Princeton University Press.

Bates, E., Camaioni, L., \& Volterra, V. (1975), 'The Acquisition of Performatives Prior to Speech'. Merrill-Palmer Quarterly, 21: 205-226.

Batkin, N. (1993), 'On Wittgenstein and Kripke: Mastering Language in Wittgenstein's Philosophical Investigations', in T. Cohen, P. Guyer and H. Putnam eds., Pursuits of Reason: Essays in Honor of Stanley Cavell. Texas: Texas Tech. University Press, 241-262.

Bell, D. (1979), Frege's Theory of Judgement. (Oxford: Clarendon Press). (1987a), 'The Art of Judgement', Mind 96: 214-44. (1987b), 'Thoughts', Notre Dame Journal of Formal Logic 28: 36-50.

Bell, R. H. ed. (1988), The Grammar of the Heart: Thinking with Kierkegaard and Wittgenstein: New Essays in Moral Philosophy and Theology. San Francisco: Harper and Row.

Boghossian, P. (1989), 'The Rule-Following Considerations', Mind 98: 507-549. (2005), 'Rules, Meaning and Intention - Discussion', Philosophical Studies 124: 185-97.

Bloor, D. (1997), Wittgenstein on Rules and Institutions, New York: Routledge.

Brooks, P. \& Kempe, V. (2012), Language Development. Chichester: BPS Blackwell.

Carroll, L. (1895), 'What the Tortoise Said to Achilles', Mind 4: 278-80.

Cohen, T., Guyer, P. \& Putnam, H. eds. (1993), Pursuits of Reason. Texas: Texas University Press.

Conant, J. (1993), 'Kierkegaard, Wittgenstein and Nonsense', in T. Cohen, P. Guyer \& H. Putnam eds., Pursuits of Reason. Texas: Texas University Press.

Crowell, S. (2007), 'Sorge or Selbstbewußtsein? Heidegger and Korsgaard on the Sources of Normativity', European Journal of Philosop by 15: 315-333.

Cloeren, H. J. (1985), 'The Linguistic Turn in Kierkegaard's Attack on Hegel', International Studies in Philosophy, 17: 1-13.

Croxall, T. H. (1956), Kierkegaard Commentary (London: Nisbet and Harpers)

Creegan, C. L. (1989), Wittgenstein and Kierkegaard: Religion, Individuality and Philosophical Method. London and New York: Routledge.

Drury, M. O'C. (1981), 'Some Notes of Conversations with Wittgenstein' in Rush Rhees, Recollections of Wittgenstein. Oxford: Blackwell.

Ferreira, M. J. (1994), The Point Outside the World: Kierkegaard and Wittgenstein on Nonsense, Paradox and Religion', Religious Studies, 30: 29-44.

_ (1998), 'Faith and the Kierkegaardian Leap', in A. Hannay \& G. D. Marino eds., The Cambridge Companion to Kierkegaard, Cambridge: Cambridge University Press, 207-234.

Finkelstein, D. (2000), 'Wittgenstein on Rules and Platonism”, in A. Crary \& R. Read eds., The New Wittgenstein. London: Routledge.

Fremstedal, R. (2006), 'Wittgenstein and Kierkegaard on the Ethico-Religious: A Contribution to the Interpretation of the Kierkegaardian Existential Philosophy in Wittgenstein's Denkbewegungen', Ideas in History 1: 109-150

Gert, J. (2015), 'Wittgenstein, Korsgaard and the Publicity of Reasons' Inquiry, 58: 439-459.

Ginsborg, H. (2011), 'Primitive Normativity and Skepticism about Rules', The Journal of Philosophy 108: $227-254$.

Groarke, L. (2009), An Aristotelian Account of Induction: Creating Something from Nothing. Montreal: McGill-Queen's University Press

Hannay, A. (1990), 'Solitary Souls and Infinite Help: Kierkegaard and Wittgenstein', History of European Ideas, 12: 41-52.

Hegel, G. W. F. (1985), Hegel: The Letters, trans. C. Butler \& C. Seller. Bloomington: Indiana University Press. 
Hustwit, R. E. (1978), 'Understanding a Suggestion of Professor Cavell's: Kierkegaard's Religious Stage as a Wittgensteinian "Form of Life"', Philosophy Research Archives, 4: 329-47.

Husserl, E. (2001), Logical Investigations: Volume 1, trans. J. N. Findlay. London: Routledge.

Johnson, R. R. (1997), 'The Logic of Leaping: Kierkegaard's Use of Hegelian Sublation', History of Philosophy Quarterly, 14: 155-170.

Kant, I. (2006), Toward Perpetual Peace and Other Writings on Politics, Peace and History, ed. P. Kleingeld \& tans. D. Colclasure. London: Yale University Press.

Kierkegaard, S (1967-78), Journals and Papers, trans. H. V. Hong \& E. H. Hong, 7 volumes. Princeton: Princeton University Press.

— (1978-2000), Kierkegaard's Writings, ed. and trans. H. V. Hong \& E. H. Hong et al., 26 volumes. Princeton, NJ: Princeton University Press.

- (1996), Papers and Journals: A Selection, ed. \& trans. A. Hannay. London: Penguin.

Korsgaard, C. (2009) Self-Constitution: Agency, Identity and Integrity. Oxford: Oxford University Press.

Kripke, S. (1981), 'Wittgenstein on Rules and Private Language: An Elementary Exposition', in Irving Block (ed.), Perspectives on the Philosophy of Wittgenstein. Oxford: Blackwell.

- (1982), Wittgenstein on Rules and Private Language. Oxford: Blackwell.

Laurence, S. \& Margolis, E. (2001), 'The Poverty of the Stimulus Argument', The British Society for the Philosophy of Science,52: 217-276.

Lippitt, J \& Hutto, D (1998), 'Making Sense of Nonsense: Kierkegaard and Wittgenstein', Proceedings of the Aristotelian Society, 98: 263-86.

Løkke, H. \& Waaler, A. (2010), 'The First Principles of Logic and the Debate about Mediation', in J. Stewart \& K. Nun (eds.), Kierkegaard and the Greek World, Tome II. Aldershot: Asgate.

Maritain, J. (1937), An Introduction to Logic. New York: Sheed \& Ward.

Martin, W. (2011), 'The Judgement of Adam', in J. Parry ed. Art and Phenomenology. London: Routledge.

McDowell, J. (1984), 'Wittgenstein on Following a Rule', Synthese 58: 325-363.

Merleau-Ponty, M. (1962), Phenomenology of Perception, trans. by Colin Smith. London: Routledge

Miles, T. (2012), 'Luwig Wittgenstein: Kierkegaard's Influence on the Origin of Analytic Philosophy' in J. Stewart ed. Kierkegaard's Influence on Philosophy, Tome 1. Aldershot: Ashgate

Miller, A. (2000), 'Horwich, Meaning and Kripke's Wittgenstein', The Philosophical Quarterly, 50: 161-174.

Minar, E. (1994), 'Paradox and Privacy: on $\$ \$ 201-202$ of Wittgenstein's Philosophical Investigations', Philosophy and Phenomenological Research 65: 43-75.

Monk, R. (1991), Ludwig Wittgenstein: The Duty of Genius. London: Vintage.

Mulligan, K. (1999), 'Justification, Rule-Breaking and the Mind', Proceedings of the Aristotelian Society 99: 123-139.

O’Brien, L. (2007), Self-Knowing Agents. Oxford: Oxford University Press.

Pears, D. (1988), The False Prison: A Study in the Development of Wittgenstein's Philosophy. Oxford: Clarendon Press.

Peckhaus, V. (2009), 'The Mathematical Origins of Nineteenth-Century Algebra of Logic', in L. Haaparanta (ed.) The Development of Modern Logic. Oxford: Oxford University Press.

Pettit, P. (1990), 'The Reality of Rule-Following', Mind: 99: 1-21.

Piaget, J. (1965), The Moral Judgement of the Child, New York: Free Press.

Plantinga, A. (1982), 'The Reformed Objection to Natural Theology', Proceedings of the American Catholic Philosophical Association 54: 49-62.

Rollefson, R. G. (2014), Thinking with Kierkegaard and Wittgenstein: The Philosophical Theology of Paul. L. Homer. Oregon: Picwick.

Shogenji, T. (2000), 'The Problem of the Criterion in Rule-Following', Philosophy and Phenomenological Research, LX: 501-525. 
Schönbaumsfeld, G. (2007), A Confusion of the Spheres: Kierkegaard and Wittgenstein on Philosophy and Religion. Oxford: Oxford University Press.

Schreiber, G. (2014), 'Leap' in S. Emmanuel, W. McDonald \& J. Stewart (eds.) Kierkegaard's Concepts Tome IV. Aldershot: Ashgare

Summerfield, D. M. (1990), 'On Taking the Rabbit of Rule-Following out of the Hat of Representation: A Response to Pettit's 'The Reality of Rule-Following', Mind 99: 425-432.

Stanovich, K. (2011), Rationality and the Reflective Mind. Oxford: Oxford University Press.

Stokes, P. (2010), Kierkegaard's Mirrors: Interest, Self and Moral Vision. Basingstoke: Palgrave Macmillan

Strichartz, A. \& Burton, R. (1990), 'Lies and Truth: A Study of the Development of the Concept', Child Development, 61: 211-220. doi:10.1111/j.1467-8624.1990.tb02773.x

Watts, D. (2007), 'The Paradox of Beginning: Hegel, Kierkegaard and Philosophical Inquiry', Inquiry, 50: 5-33.

- (2012) 'The Exemplification of Rules: An Appraisal of Pettit's Approach to the Problem of Rule-Following', International Journal of Philosophical Studies, 20: 69-90.

Williamson, T. (2000), Knowledge and its Limits. Oxford: Oxford University Press.

Wittgenstein, L. (1953), Philosophical Investigations, trans. G. E. M. Anscombe. Oxford: Blackwell.

— (1967), Zettel, eds. G. E. M. Anscombe \& G. H. von Wright, trans. G. E. M. Anscombe. Oxford: Blackwell.

— (1974a), Tractatus Logic-Philosophicus, trans. D. F. Pears \& B. F. McGuinness. London: Routledge.

(1974b), Philosophical Grammar, ed. R Rhees, trans. A. Kenny. Oxford: Blackwell.

(1975a), The Blue and Brown Books. Oxford: Blackwell.

_ (1975b), Philosophical Remarks, ed. R. Rhees, trans. R. Hargreaves \& R. White. Oxford: Blackwell.

(1975c), On Certainty, ed. G. E. M. Anscombe \& G. H. von Wright, trans. D. Paul \& G. E. M. Anscombe. Oxford: Blackwell.

(1978), Remarks on the Foundations of Mathematics, eds. G. H. von Wright, R. Rhees \& G. E. M. Anscombe, trans. G. E. M. Anscombe. Oxford: Blackwell.

Wright, C. (1980), Wittgenstein on the Foundations of Mathematics London: Duckworth.

_ (2007), 'Rule-Following Without Reasons: Wittgenstein's Quietism and the Constitutive Question', Ratio 20: 481-502.

\footnotetext{
1 Drury 1981: 87

2 This tendency is indeed natural, given that Wittgenstein's explicit remarks about Kierkegaard typically touch on religious questions. For fine surveys of Wittgenstein's references to Kierkegaard, see Schönbaumsfeld 200, Ch. 1; and Miles 2012. For studies on the Kierkegaard / Wittgenstein relationship that focus on philosophy of religion, see also Bell 1988; Creegan 1989; Conant 1993; Ferreira 1994; Fremstedal 2006; Hannay 1990; Hustwit 1978; Lippitt \& Hutto 1998; Rollefson 2014.

3 I take this scenario from Miller 2000: 172.

4 For a discussion of the regular behaviour of hoverflies, vis-à-vis rule-following, see Millikan 1990: 330ff.

5 One model of such a process of 'internalisation' is given by 'dual process theory' in contemporary cognitive psychology. In this model, 'System 1' processing is automatic, fast, high capacity and unconscious; whereas 'System 2' processing is controlled, slower, limited in capacity and conscious. System 1 is said to harbour acquired response tendencies including 'many rules, stimulus discriminations, and decision-making principles that have been practiced to automaticity' (Stanovich, 2011: 20).
} 
6 Notably, Boghossian has more recently recanted this part of his influential work on rule-following. See Bohossian 2005: 194ff.

7 Compare also Tomoji Shogenji's clam that rule-following involves conformity plus 'subscription' to a rule (Shogenji 2000: 503).

8 Cf. Wittgenstein 1953: $\iint 455,457$. Hereafter, this text is cited using the conventional abbreviation ' $P P$ ', followed by section number.

9 Cf. Wittgenstein 1978: VII-60: 'notbing stands between the rule and my action'.

10 See also Bell 1979 and Bell 1987b.

11 This issue returns throughout Wittgenstein's later work, including On Certainty. See, for example, his remark there that ' $[1]$ anguage did not emerge from some kind of ratiocination' (Wittgenstein 1975c \$475).

12 Noting his returning interest in the (non-empirical) conditions of teaching and learning language, Baker and Hacker comment that, for Wittgenstein, 'explanations presuppose a background of prior understanding, a partial linguistic competence' (Baker and Hacker 1980: 30). As they also observe, critics often overlook the centrality of Wittgenstein's interest in the conditions of teaching and learning. To the question, '[a]m I doing child psychology?', Wittgenstein answers: 'I am making a connection between the concept of teaching and the concept of meaning' (Wittgenstein 1967: \$412). The connection, I take it, is that teaching does not, in the first instance, consist in the transferal of mental items ('meanings') to be grasped by special mental processes, but rather in eliciting certain forms of spontaneous response.

13 Compare: 'To begin by teaching someone "that looks red" makes no sense. For he must say that spontaneously once he knows what "red" means, i.e. has learnt the technique of using the word" (Wittgenstein 1967: §418).

14 Compare Kripke's reference to 'the incredible and self-defeating conclusion that all language is meaningless' (Kripke 1981: 273).

15 See McDowell 1984. Compare also Finkelstein 2000; Minar 1994; Summerfield 1990.

16 For a compelling case that Korsgaard's version of the appeal to 'internalized' explicit rule-following, in particular, remains vulnerable to this line of objection, see Gert 2014. See also Korsgaard 2009: 107; Crowell 2007. For an application of a similar line of objection to Phillip Pettit's account of rule-following, see Watts 2012.

17 See, e.g., Millikan 1990.

18 For other mentions of 'leaps' in the literature on rule-following see David Pears' reference to the idea that 'sooner or later there will have to be a leap, not guaranteed by any definition, from language to the world' (Pears, 1988: Vol. 2, 432n10); Crispin Wright's discussion of the idea that 'understanding an expression is a kind of "cottoning on"; that is, a leap, an inspired guess at the pattern of application which the instructor is trying to get across' (Wright 1980: 216); Phillip Pettit's remark that 'rule-following, as I understand it, does not encompass the full leap from protoplasm to personhood, only the transition from subpersonal to personal mentality' (Pettit 1990: 2). See also Wittgenstein himself, cited in the main text below. No doubt these various uses of the metaphor of leaping are indeed various. But it is striking how frequently the image shows up in this literature.

19 It is not part of my aim to show that Kierkegaard addresses directly the question of the nature of rules and the conditions of their representation by finite sets of examples.

20 Of Kierkegaard's leap, T. H. Croxall baldly asserts, that 'in every case this leap is a leap of Faith ... it is a religious movement' (Croxall 1956: 20). In fact, as M. Jamie Ferreira observed, Kierkegaard never actually used the phrase 'leap of faith' (see Ferreira 1998: 207). For a helpful synopsis of references to the leap in Kierkegaard, see Schreiber 2014.

${ }_{21}$ See e.g. KIW VII: 43. Kierkegaard appears to approach the sorites in the Stoic way, recently revived by Timothy Williamson and others, as showing that the boundaries of certain features or qualities are determinate but unknowable (cf. Williamson 2000). 
22 Moreover, for many in Kierkegaard's milieu, Hegel's logic held out the promise of providing a sort of grounding for basic principles such as the principle of non-contradiction. Thus according to F. C. Sibbern, in Hegel's system, 'the so-called law of contradiction is actually recognized according to its genuine meaning' (cited in Løkke \& Waaler 2010: 7)

23 On Trendelenburg's 'Logical Question', see Peckhaus 2009:174.

24 On the non-discursive character of Aristotelian epagoge, see Maritain 1937: 273-274; Groarke: 2009.

25 Compare also Wittgenstein's questioning of 'the hardness of the logical must' (PI $\$ 437$ ).

${ }_{26}$ For a fuller account of Kierkegaard's critique of Hegel on this score, see Watts 2007.

${ }_{27}$ Cf. Wittgenstein 1975a: 142-3: “"The rule meant him to follow up 100 by 101" makes it appear that this rule, as it was meant, foreshadowed all the transitions which were to be made according to it. But the assumption of a shadow of a transition does not get any further, because it does not bridge the gulf between it and the real transition." See also PI $\$ 431$.

28 Kierkegaard's emphasis on the 'integrative commonality' that is an essential condition of language is just one evidence that, insofar as his work expresses any sort of 'individualism', this is not atomism.

29 Cf. $K W$ II: 276.

30 In the case of Hegel, this moral seems rather borne out by Ottilie von Goethe's delightful recounting of a lunch with her father-in-law and Hegel in Weimar in October 1827:

'During the meal Goethe was comparatively quiet. No doubt so as not to disturb the free speech of his very voluble and logically penetrating guest, who elaborated upon himself in oddly complicated grammatical forms. An entirely novel terminology, a mode of expression overleaping itself, the peculiarly employed philosophical formulas of the ever more animated man in the course of his demonstrations all this finally reduced Goethe to complete silence without the guest even noticing. The lady of the house likewise listened in silence, no doubt somewhat taken aback, and glanced at "father" - as she always called Goethe. After the meal had ended and the guest departed, Goethe asked his daughter: "Now did you like the man?" "Strange," she replied, "I cannot tell whether he is brilliant or mad. He seems to me to be an unclear thinker." Goethe smiled ironically. "Well, well, we just ate with the most famous of modern philosophers_Georg Wilhelm Friedrich Hegel.”” (Hegel 1985: 50).

It is also worth noting here that Kierkegaard strikingly anticipates Wittgenstein's famous image of language going 'on holiday' when, apropos Hegel's speculative assimilation of Christian terminology, he sardonically suggests that soon 'language will celebrate a great sabbatical year' (KWVIII: 12).

31 See Mulligan 1999. While Mulligan makes no mention of Kierkegaard, his remarks fits well with the account I shall extrapolate from Anxiety: 'Rule-breakings announce themselves as feelings of unease, and other manifestations of Sprachgefühl and of Rechtsgefühl ... the pangs, qualms and 'bites' of conscience (cognitive and linguistic as well as ethical) tell me what I ought not to do, not what I should do' (Mulligan 1999: 131).

32 For a rich discussion of this problem regarding the Genesis narrative, apropos Cranach's Garden of Eden, see Martin 2011.

33 It is perhaps surprising how far Kierkegaard's text is prepared to 'de-theologize' the Genesis narrative in this way. It is worth noting, however, that Haufniensis appears to introduce God back into the picture when he writes, in a footnote to his suggestion that we take the 'speaker' of the putatively divine prohibition to be language itself, that if the question then becomes one about the origins of language, 'this much is certain, that it will not to do represent man himself as the inventor of language' (KWVIII: 47).

${ }_{34}$ Chapter Two of Anxiety fully exploits in this connection the phenomenology of peering into an abyss and feeling both attracted and repelled by the possibility of throwing oneself off (see $K W$ VIII: $61 \mathrm{ff}$ ). In the wider context of Kierkegaard's work, this description of the precariousness of Adam's predicament reflects the view that the most fundamental expression of human freedom is not the decision between good and evil, or virtue and vice, but between sin and faith (cf. KW XIX: 82ff).

35 This qualification reveals an important feature of Haufniensis' interpretation of Genesis, inasmuch as he reads Adam as emblematic of human childhood and childlikeness: 'The anxiety that is posited in 
innocence is... no suffering that cannot be brought into harmony with the blessedness of innocence. In observing children, one will discover this anxiety intimated more particularly as a seeking for the adventurous, the monstrous and the enigmatic ... This anxiety belongs so essentially to the child that he cannot do without it, it captivates him by its pleasing anxiousness' (KWVIII: 42).

36 Kierkegaard comments on the 'double meaning expressed in the word 'interest' [interesse]' in his unfinished novella, Johannes Climacus (KW VII: 170.) For a full treatment of the wider significance of this term in Kierkegaard's writings, see Stokes 2010.

37 See Merleau-Ponty 1962: 109.

38 I borrow the term 'agent's-awareness' from Lucy O'Brien. See her fine analysis in O'Brien 2007.

39 The inability of young children to distinguish lies from inadvertent falsehoods is well-documented in developmental psychology. See, for example, Piaget 1965, Strichartz \& Burton 1990.

40 See, for example, the discussion of the divergent systems of colour terms in English and the Nambian Himba tribe in Brooks \& Kempe 2012, p. 171ff.

41 Of the consequence of Adam's eating the forbidden fruit, Kant writes: 'He discovered in himself a capacity to choose a way of life for himself and not, as the other animals, to be bound to a single one. The momentary delight caused by his noticing this advantage must have been followed by anxiety and fear as to how he, not having known anything according to its hidden traits and remote effects, should proceed with his newly discovered ability. He stood at the edge of an abyss, as it were.' (Kant 2006: 2627)

42 This idea of a primitive normative orientation informs Haufniensis' discussion of sex in Eden. He presents it as a consequence of the Fall that 'the sensual' is transformed into 'the sexual', so that Adam's and Eve's relationship to the first Biblical command, to 'be fruitful and multiply', now becomes reflective, self-conscious, shame-riven (compare Velleman 2001). But Haufniensis also insists that it does not follow that prelapsarian sensuality is merely instinctive; to suppose this, he insists, would be to work with a false dichotomy between blind instinct and reflective self-consciousness (see KW VIII: 68-71).

43 I am grateful to an anonymous reviewer for this journal for pressing me on this point.

${ }_{44}$ Further support for this conclusion can be garnered from the considerations behind Chomsky's Poverty of the Stimulus argument, the force of which is independent from the hypothesis of universal grammar. On these considerations, see Laurence \& Margolis 2001.

45 For one influential developmental account of competence with imperatives, see Bates et al. 1975.

46 Compare Crispin Wright's discussion, apropos Wittgenstein, of conceptions of rule-following that require 'a conceptual repertoire anterior to an understanding of any particular rule'. Wright comments: 'From the standpoint of the philosophy of thought and language of the Investigations, this is an enormous mistake. With respect to a wide class of concepts, a grasp of them is not anterior to the ability to give them competent linguistic expression but rather resides in that very ability' (Wright 2007: 496).

47 Compare Hannah Ginsborg's Kant-inspired attempt also to supply an account of primitive normativity that provides a middle way between an intentionalist conception of rule-following and mere ruleconforming (see Ginsborg 2011: 248, n25). On Ginsborg's account, it is sufficient for one to follow a rule just for one to be reliably disposed to conform to the rule, 'with the proviso that one's ... behavior involves the consciousness of its primitive appropriateness to the context' (Ginsborg 2011: 248). Notably, the view I am associating with Kierkegaard does not require any positive idea of consciousness of the 'primitive appropriateness' of one's way of applying a rule. Rather, it requires only pre-reflective awareness of the possibility of one's doing otherwise than the rule requires.

48 See Monk 1991: 64.

49 Warm thanks to the following people, for their help with this paper and critical discussion: David Batho, David Bell, Matteo Falomi, Fabian Freyenhagen and, especially, Béatrice Han-Pile. 